\title{
A new method to quantify macroalgae and a practical sampler for experimentation in lotic habitats
}

\author{
Tonetto, $A F^{a}{ }^{a}$, Peres, $C K .^{b}$ and Branco, $C C Z .^{a *}$ \\ ${ }^{a}$ Faculdade de Ciências e Letras de Assis, Universidade Estadual Paulista - UNESP, \\ Av. Dom Antônio, 2100, Parque Universitário, CEP 19800-000, Assis, SP, Brazil

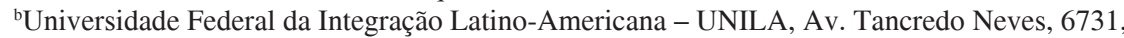 \\ Parque Tecnológico Itaipu, CEP 85867-970, Foz do Iguaçu, PR, Brazil \\ *e-mail: czbranco.assis.unesp.br \\ Received October 21, 2011 - Accepted January 25, 2012 - Distributed November 30, 2012
}

(With 2 figures)

\begin{abstract}
Experimental studies in rivers and streams are extremely difficult to run due to the fact that the conditions of these environments are very complex and provide a high level of heterogeneity, which hinders the precise control and standardization of variables. In this study, we present a practical sampler that was designed to make it easier to conduct research projects involving benthic communities of lotic environments, as well as a new nondestructive technique for quantification of the macroalgal communities typically found in these habitats. The sampler consists of an acrylic square tube in which water flows normally inside. This structure carries a removable glass plaque with a known area and can simulate various ecological situations by changing both biotic and abiotic conditions. Thus, it can mitigate the differences between environmental characteristics where each sampler is exposed. The new technique involves capturing digital images that can monitor a unique macroalgal community in development throughout time and a more precise quantification when compared with other techniques that are widely applied. The sampler is easy to build and the images simple to quantify, allowing the detection of spatial and temporal variations in richness and abundance of investigated communities.
\end{abstract}

Keywords: artificial substrate, sampling method, stream macroalgae, limnology.

\section{Um novo método para quantificar macroalgas e um prático amostrador para experimentação em ecossistemas lóticos}

\begin{abstract}
Resumo
Os estudos experimentais em rios e riachos são extremamente difíceis de serem executados, visto que as condições desses ambientes são muito complexas e proporcionam um alto nível de heterogeneidade, o que dificulta o controle e a padronização precisa das variáveis. Nesse contexto, um prático amostrador foi desenvolvido para facilitar a execução de projetos de pesquisas envolvendo comunidades bentônicas de ambientes lóticos, além de constituir uma nova técnica não destrutiva para quantificação das macroalgas tipicamente encontradas nesses habitats. O amostrador consiste de um tubo de acrílico de seção quadrada, pelo qual a água corrente flui normalmente em seu interior. Tal estrutura porta uma placa de vidro removível com área conhecida e permite simular diversas situações ecológicas, variando tanto as condições abióticas como as bióticas, além de amenizar as diferenças entre as características ambientais a que está submetido cada um dos amostradores. Diversamente, a nova técnica consiste na captura de imagens digitais que permitem o acompanhamento temporal de uma mesma comunidade de macroalgas em desenvolvimento e uma quantificação mais precisa quando comparada com técnicas amplamente aplicadas na área. O amostrador é fácil de construir e as imagens são simples para quantificar, permitindo a detecção de variações espaço-temporais na riqueza e abundância das comunidades investigadas.
\end{abstract}

Palavras-chave: substratos artificiais, método de amostragem, macroalgas de riachos, limnologia.

\section{Introduction}

Among the various primary producers from the benthic community of lotic environments, the algal element has been described as one of the most important (Lamberti, 1996; Necchi Junior et al., 2003; Branco et al., 2008). The

algae community can establish itself in different ways and arrangements and an important form of algal flora is constituted by species that show noticeable macroscopic development. In other words, they are recognizable by the 
naked eye (John and Moore, 1985; Sheath et al., 1989), which is a trait that explains why they have been traditionally reported as lotic macroalgae (Sheath and Cole, 1992).

However, the overlapping between macroalgae and periphytic communities is inevitable (Wetzel, 1983), which is explained by the noticeable coexistence of these organisms in the environment where they live, making the delimitation of limits between micro (periphyton) and macroscopic (macroalgae) elements extremely difficult. In this context, there is a fundamental point which is carefully worked out from this verification: the methodology, which needs to be coherent with peculiarities from the community.

Some studies involving autotrophic communities, such as periphytic or macroalgae, evaluate the responses from algal community by a series of accepted and useful methods (Wetzel, 1981, 1983). Among the most useful methods, we may cite: chlorophyll $a$ extraction (Marker et al., 1980; Sartory and Grobbellar, 1984) and the quantification of dry mass and ash free dry mass (Schwarzbold et al., 1990). Additionally, the distribution of macroalgae in a specific area or region is frequently analyzed in the field using a transect technique associated to a visual estimation of abundance which gives the relative percentage of an area covered by algae in the environment (Sheath and Cole, 1992).

However, these methods are relatively inaccurate. For example, dry mass and/or ash free dry mass evaluation of the macroalgal community could include other organisms such as microalgae and non-algae organisms associated with their stalks (Sheath and Cole, 1992). Thus, all associated organisms and accumulated organic material would be inevitably quantified.

Likewise, results from analysis involving photosynthetic pigments (e.g. chlorophyll $a$ ) can be significantly altered due to interference from associated algal elements. On the other hand, the visual estimative technique from percentage cover extensively used in fieldwork is a useful semi-quantitative technique in ecological studies, which compares parts of streams. However, this procedure has become problematic for refined experimental studies because it depends on the observer and does not give absolute numbers.

Studies on the effects of abiotic variables in lotic macroalgae, such as physical, chemical or temporal variables, have used some methodological strategies that involves the use and application of both natural (Sládedkowá, 1962; Wetzel, 1965; Soares, 1981) and artificial substrates (Cattaneo et al., 1975; Panitz, 1980). In 1916, Hentschel was the first to use microscope slides and other kinds of substrates in qualitative and quantitative studies on periphyton (Sládedkowá, 1962). Since then, various studies have been carried out using artificial substrates (Schwarzbold, 1990).

The non-natural substrates are widely used in ecological studies because they are user- friendly and can be compared with the natural environment. Ecological studies on producer communities associated with artificial substrates in lotic environments are common in the literature (Biggs, 1988; Clifford et al., 1992; Fernandes and Esteves, 2003;
Lobo et al., 2004; Barbee, 2005; Salomoni et al., 2007; Canani et al., 2010).

However, most studies have been dedicated to periphytic communities (Biggs, 1988; Biggs and Close, 1989; Hoagland et al., 1982; Stevenson and Peterson, 1991). Hence, the macroscopic portion of producer communities in these environments, especially macroalgae (sensu Sheath and Cole, 1992), are rarely studied (Dudley and D'Antonio, 1991; Downes, 2000; Branco et al., 2010).

Thus, in order to obtain more precise and specific data about such communities we developed a practical model for the use of artificial substrates and a new methodology for lotic macroalgae quantification. This novel methodological model will be able to make macroalgae assessments and standardization of these studies more precise.

\section{The Sampler}

Our sampler is proposed for the application of artificial substrates (modified from Peterson et al., 1983). It is made of transparent acrylic pieces that were welded to form a square tube measuring approximately $15 \mathrm{~cm}$ length, $8 \mathrm{~cm}$ width and $8 \mathrm{~cm}$ height. There are slots to fit a removable rectangular slide inside the tubes, which work as artificial substrates for algal colonization (see Figure 1).

This model can simulate various environmental conditions, as follows: 1) different levels of light intensity by covering the tube walls with light reducing films (described by Tonetto, 2010); 2) various substrate types which can be made in different forms or with different
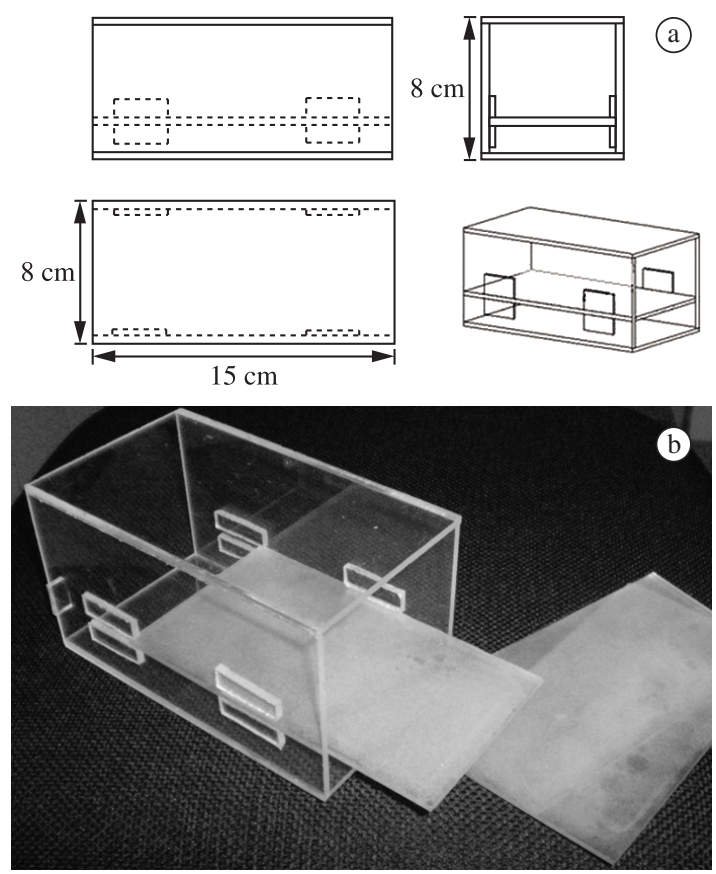

Figure 1. a) Schematic drawing of the sampler made by acrylic plaques and with a removable glass slide inside. b) Photo illustrating the sampler. 
materials; 3 ) different chemical conditions (e.g. nutrients and polluters), using diffuser substrates that can gradually release substances, and; 4) herbivore levels, using mesh to selectively control herbivores.

The sampler can also be built in different sizes, with larger lengths and transverse areas depending on the research goals. Additionally, it has important inert characteristics and a defined area that can investigate the macroalgae biomass variation. The sampler is easy to be produced, it has a low cost of production and is made of renewable materials. However, certain precautions should be observed when installing and maintaining the samplers in streams. For the installation, the samplers should be fixed using some heavy material to ensure their stability and total submersion in the lotic environment. This procedure prevents the movement of the sampler due to the flow. We recommended that the samplers are attached, using stainless steel wire, to a plywood board associated with a concrete base of approximately $15 \mathrm{~kg}$ (as proposed by Biggs, 1988). To maintain the samplers throughout the experimental period, the biofilm should be removed periodically (using a soft brush) that might cover the external and internal walls of the samplers. This procedure avoids any interference in the availability of light within it. Regular maintenance is also important to remove any debris (manually) that may be retained on the samplers.

It is worth mentioning that the number of samplers used in each study must be calculated considering the objective of the study and especially the high heterogeneity typically found in lotic environments.

\section{The Technique}

The presented technique has been proposed to improve the accuracy of quantitative assessment of benthic algal communities, with special emphasis on the stream macroalgae, by applying a technique never used for these communities. The quantification offered by this study is based on the covering percentage; it means that this technique represents better the competition for establishment of macroalgae in a determined space. For this purpose, the procedure described here is based on similar techniques used in other areas of scientific research, which are based on analyzing digital pictures, such as the ones that evaluate the foliar area of plants (Godoy et al., 2007; Rico-Garcia et al., 2009) or the canopy cover of woody areas (Canham, 1988; Englund et al., 2000).

Hence, the removable slides, inserted into the sampler described above, can be removed from the tubes and some pictures can be taken. The pictures should have a high resolution to ensure that the algae which are colonizing the substrate can be clearly seen. For standardization purposes, photos must be taken with the camera $15 \mathrm{~cm}$ (in height) far from the colonized slides. To help analysis pictures in the laboratory, we recommend the researcher to map the slide in the field notes. This can be useful when looking for determined species on pictures. The process takes less than 5 minutes until the slides return to the samplers, preventing damage to algae communities due to desiccation.

To ensure this method is used to its full potential and also the quality of the results, specimens from the natural substrates should be collected. In the laboratory, based on morphological forms, the collected material can be linked with macroalgae presented in the pictures.

After photographic documentation, the pictures of the artificial substrates that had been colonized can be analyzed using software (AutoCAD ${ }^{\circledR}$ or other software with similar functions), with the objective of quantifying the community and each species individually. Considering this, the area colonized by each species (in each photograph) should be marked and estimated in terms of the percentage of the total area of the substrate (see Figure 2).

This method is more accurate to determine the area occupied by the macroalgae flora, which represents an advance when compared with the estimative visual technique, which was applied earlier. In order to calibrate the quantification method, it is important to establish the same scale for all images. Although the analyses of covering percentage is a semi quantitative method, it is not destructive, which ensures absence of the algal biomass loss. Moreover, monitoring the temporal variation of the sampled macroalgae communities is more realistic, since the same community is periodically evaluated rather than different samples collected on separated dates. Therefore, our method can be the most appropriate to quantify macroalgae abundance through time.
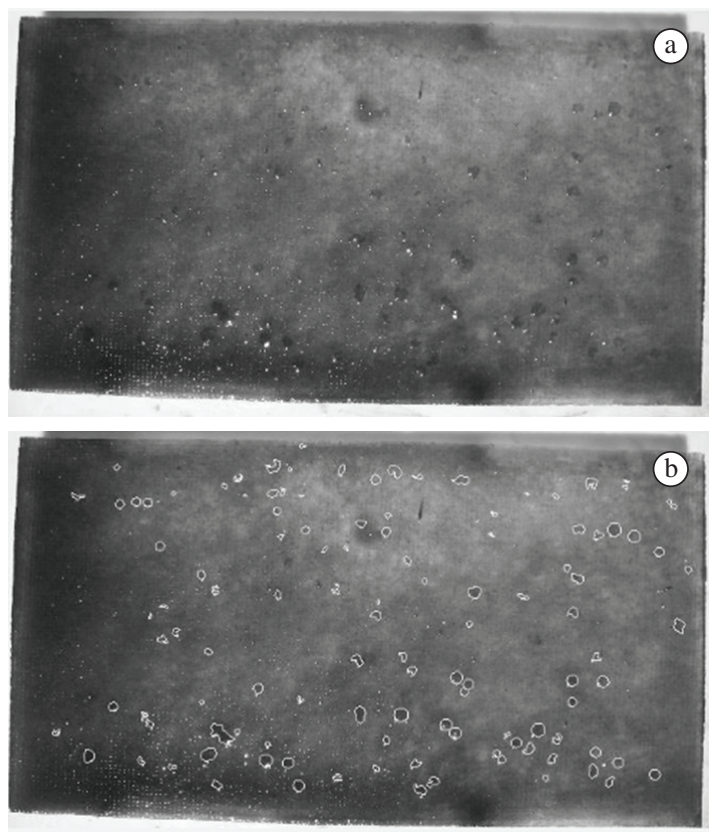

Figure 2. a) Photograph of an artificial substrate colonized by macroalgae (in this case, Tetraspora lubrica). b) The same photograph with the demarcated areas occupied by macroalgae in computer software. 
The sampler and the technique described were used in an experimental study, where the colonization of the macroalgal community was observed over a period of 91 days in four streams in southern Brazil (Tonetto, 2010). During this experimental period, $100 \%$ of the glass plaques remained intact, showing high durability of the sampler. The flow of water and light availability within the samplers were not affected, while the analysis technique proved to be easy to use and highly accurate in terms of quantifying the biomass of macroalgae.

In conclusion, using the samplers described in this paper and applying the quantification described here, researchers have a powerful tool to obtain more precise results from the lotic macroalgal communities. By using our model, researchers will be able to enhance the practicability and versatility of their work and, at the same time, save time and financial resources.

Acknowledgement - We would like to thank CNPq (Conselho Nacional de Desenvolvimento Científico e Tecnológico) and CAPES (Coordenação de Aperfeiçoamento de Pessoal de Nível Superior) for the financial support. We would also like to thank Rhainer Guillermo Nascimento Ferreira and Ricardo Cardoso Leite for their valuable help in proofreading the text.

\section{References}

BARBEE, NC., 2005. Grazing insects reduce algal biomass in a neotropical stream. Hydrobiologia, vol. 532, p.153-165.

BIGGS, BJF., 1988. A periphyton sampler for shallow, swift rivers. New Zealand Journal of Marine \& Freshwater Research, vol. 22, p.189-199. http://dx.doi.org/10.1080/00288330.1988.9516291

BIGGS, BJE. and CLOSE, ME., 1989. Periphyton biomass dynamics in gravel bed rivers: The relative effects of flows and nutrients. Freshwater Biology, vol. 22, p. 209-231. http://dx.doi. org/10.1111/j.1365-2427.1989.tb01096.x

BRANCO, CCZ., KRUPEK, RA. and PERES, CK., 2008. Seasonality of macroalgal communities in a subtropical drainage basin in Paraná State, southern Brazil. Brazilian Journal of Biology, vol. 68, p. 631-637.

BRANCO, CCZ., NECCHI JUNIOR, O. and PERES, KP., 2010. Effects of artificial substratum types and exposure time on macroalgal colonization in a tropical stream. Fundamental and Applied Limnology, vol. 178, no. 1, p. 17-27. http://dx.doi. org/10.1127/1863-9135/2010/0178-0017

CANANI, LGC., TORGAN, LC. and MENEZES, M. 2010. Gadget for Epilithic Microalgal Sampling (GEMS). Brazilian Journal of Biology, vol. 70, no. 2, p. 289-291. http://dx.doi.org/10.1590/ S1519-69842010005000007

CANHAM, CD., 1988. An index of understory light levels in and around canopy gaps. Ecology, vol. 69, p. 1634-1703. http:// dx.doi.org/10.2307/1941664

CATTANEO, A., GHITTORI, S. and VENDEGNA, V., 1975. The development of benthonic phytocenosis on artificial substrates in the Ticiano river. Oecologia, vol. 19, p. 315-327.

CLIFFORD, HF., CASEY, RJ. and SAFFRAN, KA., 1992. Short-term colonization of rough anh smooth tiles by benthic macroinvertebrates and algae (chlorophyll a) in two streams.
Journal of the North American Benthological Society, vol. 11, p. 304-315. http://dx.doi.org/10.2307/1467650

DOWNES, BJ., LAKE, PS. and SCHREIBER, ESG., 2000. Habiata structure, resources and diversity: the separate effects os surface roughness and macroalgae on stream invertebrates. Oecologia, vol. 123, p. 569-581. http://dx.doi.org/10.1007/PL00008862

DUDLEY, TL. and D'ANTONIO, CM., 1991. The effects of surface texture, grazing, and disturbance on macroalgal establishment in streams. Ecology, vol. 72, p. 297-304. http:// dx.doi.org/10.2307/1938923

ENGLUND, SR., O'BRIEN, JJ. and CLARK, DB., 2000. Evaluation of digital and film hemispherical photography and spherical densiometry for measuring forest light environments. Canadian Journal of Forest Research, vol. 30, p. 1999-2005. http://dx.doi.org/10.1139/x00-116

FERNANDES, VO. and ESTEVES, FA., 2003. The use of índices for evaluating the periphytic community in two kinds of substrate in Imboassica Lagoon, Rio de Janeiro, Brazil. Brazilian Journal of Biology, vol. 63, p. 1-16. PMid:12914409.

GODOY, LJG., YANAGIWARA, RS., BÔAS, RLV., BACKES, C. and LIMA, CP., 2007. Análise da imagem digital para estimativa da área foliar em plantas de laranja "Pêra". Revista Brasileira de Fruticultura, vol. 29, no. 3, p. 420-424.

HOAGLAND, KD., ROEMER, SC. and ROSOWSKI, JR., 1982. Colonization and community structure of two periphyton assemblages, with emphasis on the diatoms (Bacillariophyceae). American Journal of Botany, vol. 69, p. 188-213. http://dx.doi.org/10.2307/2443006

JOHN, DM. and MOORE, JA., 1985. Observations on the phytobenthos of freshwater Thames II. The floristic composition and distribution of the smaller algae sample using artificial surfaces. Archives of Hydrobiology, vol. 103, no. 1, p. 83-97.

LAMBERTI, GA., 1996. The role of periphyton in benthic food webs. In STEVENSON, RJ., BOTHWELL, M. and LOWE, RL. (Eds.). Algal Ecology, Freshwater Benthic Ecossystems. San Diego: Academic Press. p. 533-564.

LOBO, EA., CALLEGARO, VLM., HRMANY, G., BES, D., WETZEL, CA. and OLIVEIRA, MA., 2004. Use of epilithic diatoms as bioindicators from lotic systems in southern Brazil, with special emphasis on eutrophycation. Acta Limnologica Brasiliensia, vol. 16, p. 25-40.

MARKER, AFH., NUSCH, H., RAI, H. and RIEMANN, B., 1980. The measurement of photosynthetic pigments infreshwaters and standardization of methods: conclusion and recommendations. Archives of Hydrobiology Beih, vol. 14, p. 91-106.

NECCHI JUNIOR, O., BRANCO, LHZ. and BRANCO, CCZ., 2003. Ecological distribution of stream macroalgal communities from a drainage basin in the Serra da Canastra National Park, Minas Gerais, Southeastern Brazil. Brazilian Journal of Biology, vol. 63, no. 4, p. 1-12. http://dx.doi.org/10.1590/S1519-69842003000400010

PANITZ, CMN., 1980. Estudo comparativo de diferentes substratos artificiais na represa do Lobo ("Broa"). São Carlos: Universidade Federal de São Carlos. 224 p. Dissertação de Mestrado.

PETERSON, BJ., HOBBIE, JE. and CORLISS, TL., 1983. A Continuous-flow periphyton bioassay: tests of nutrient limitation in a tundra stream. Limnology \& Oceanography, vol. 28, no. 3, p. 583-591. http://dx.doi.org/10.4319/lo.1983.28.3.0583

RICO-GARCÍA, E., HERNÁNDEZ-HERNÁNDEZ, F., SOTOZARAZÚA, GM. and HERRERA-RUIZ, G., 2009. Two new 
Methods for the Estimation of Leaf Area using Digital Photography. International Journal of Agriculture and Biology, vol. 11, no. 4, p. 397-400.

SALOMONI, SE., TORGAN, LC. and ROCHA, O., 2007. Sampler collection gadget for epilithic diatoms. Revista Brasileira de Biologia $=$ Brazilian Journal of Biology, vol. 67, no. 4, p. 631-637.

SARTORY, DP. and GROBBELLAR, JU., 1984. Extraction of chlorophyll a from freshwater phytoplankton for spectrophotometric analysis. Hydrobiologia, vol. 114, p. 177-187. http://dx.doi. org/10.1007/BF00031869

SCHWARZBOLD, A., 1990. Métodos ecológicos aplicados ao estudo do perifíton. Acta Limnologica Brasiliensia, vol. 3, p. 545-592.

SCHWARZBOLD, A., ESTEVES, FA. and PANOSSO, RF., 1990. Relações entre peso seco e clorofila a do perifíton em função de diferentes idades e épocas de coletas de pecíolos de Eichhornia azurea Kunth. Acta Limnologica Brasiliensia, vol. 3, p. 493-515.

SHEATH, RG. and COLE, KM., 1992. Biogeography of stream magroalgal in North America. Journal of Phycology, vol. 28, p. 448-460. http://dx.doi.org/10.1111/j.0022-3646.1992.00448.x

SHEATH, RG., HAMILTON, PB., HAMBROOK, JA. and COLE, KM., 1989. Stream macroalgae of eastern boreal forest region of North America. Canadian Journal of Botany, vol. 67, p. 3553-3562. http://dx.doi.org/10.1139/b89-437
SLÁDEDKOWÁ, A., 1962. Limnological investigation methods for the periphyton ("aufwuchs") community. Botanical Review, vol. 28 , p. $236-350$.

SOARES, JJ., 1981. Estudos sobre biomassa e produtividade do perifíton em macrófitas na Represa do Lobo. São Carlos: Universidade Federal de São Carlos. 233 p. Tese de Doutorado.

STEVENSON, RJ. and PETERSON, CG., 1991. Emigration and immigration can be important determinants of benthic diatom assemblages in streams. Freshwater Biology, vol. 26, p. 295-306.

TONETTO, AF., 2010. Efeitos da irradiância e da composição espectral da luz sobre o estabelecimento e desenvolvimento de comunidades de macroalgas lóticas em substratos artificiais. Rio Claro: Universidade Estadual Paulista. 55 p. Dissertação de Mestrado.

WETZEL, RG., 1965. Techniques and problems of primary productivity measurements in higher aquatic plants and periphyton. Memorie dell Instituto italiano de hidrobiologia. Dott Marco de machi, vol. 18 , p. 240-267.

-, 1983. Periphyton of freshwater ecosystems developments. In Proceedings of the First International Workshop on Periphyton of Freshwater Ecosystems, 1983. The Hague: B. V. Junk Publishers. Developments in Hydrobiology: vol. 17, 364 p.

-, 1981. Limnologia. Barcelona: Omega. 679 p. 
